\title{
The Second International Conference for the Exploration of the Sea, Christiania, 1901.
}

ON the invitation of the Norwegian Government a second International Conference met at Christiania in May, 1901, to revise and complete the proposals formulated at the Stockholm Conference in 1899 for a combined hydrographical and biological exploration of the North Sea and adjoining waters in the interests of the sea-fisheries.

The delegates appointed by the various Governments to attend the Conference were as follows:-

Norway.--Prof. F. Nansen, Dr. J. Hjort.

Sweden.-Prof. O. Pettersson, Prof. P. T. Cleve, Mr. G. Ekman, Capt. E. G. D. Maechel, Dr. F. Trybom, Mr. A. Wijkander.

Russia.-Prof. O. von Grimm, Dr. N. Knipowitsch.

Finland.-Dr. O. Nordquist.

Germany.-Dr. H. Herwig, Prof. K. Brandt, Prof. F. Heincke, Prof. H. Henking, Prof. O. Krümmel.

Denmark.-Capt. C. F. Drechsel, Dr. M. Knudsen, Dr. C. G. J. Petersen.

Holland.-Prof. P. P. C. Hoek.

Belgium.-Prof. G. Gilson, Mr. R. Andvord.

Great Britain.-Sir Colin Scott Moncrieff, Prof. D'Arcy W. Thompson, Mr. W. Garstang, Dr. H. R. Mill.

The Report of the Conference has recently been issued, and contains minutes of each day's proceedings and the Resolutions of the Conference. A translation of the former and the authorised English version of the Resolutions are given below.

The Programme of Researches is included under the Resolutions. It embodies a comprehensive scheme of investigations designed to throw light on the various problems to which the representatives of the differ- 
ent nationalities attached importance. Prominence has been given to questions concerning the irregular fluctuations in the yield of the line and drift-net fisheries, to the alleged impoverishment of the trawling grounds, and to the destruction of immature (undersized) fish. The physical and biological investigations which the Conference has resolved upon in connection with these matters are minutely detailed in the programme, which is subdivided into sections according to the character of the work proposed. A characteristic feature of the biological programme is its division into obligatory and optional sections-an arrangement which provides the elasticity necessary for so large an undertaking, while adequately safeguarding the international character of the fundamental inquiries. The investigation of the distribution and destruction of immature (undersized) fish forms part of the obligatory programme.

The general idea of the international programme is as follows:-

I. To obtain an accurate knowledge of the seasonal and other periodic changes in the waters of the North and Northern Seas, both as regards the distribution of temperature, salinity, etc., and also as regards the course and distribution of the currents. (Recent scientific observations on a limited scale have rendered it probable that in some years Arctic water, and in others Atlantic water, predominates in the North Sea basin,-changes of such magnitude that obviously the distribution of food-fishes and of other animals throughout this area must be profoundly affected.)

II. To determine the amount of variation in the character and abundance of the food-supply of food-fishes, whether floating (i.e. plankton) or on the sea-bed.

III. To determine the variations in the abundance and distribution of food-fishes, both in the egg, young, and adult conditions.

IV. To determine the extent to which these variations are due, either (a) directly to natural physical causes; or (b) indirectly to the same causes through fluctuations in the food-supply; or $(c)$ to the operations of fishing-vessels in modifying the natural conditions of reproduction and growth.

V. To provide other information necessary for the consideration of remedial measures; e.g. artificial propagation, effect of special fishing implements, new methods, places and seasons of fishing, size limits.

In order to carry out the international programme each of the participating countries needs its own local organisation and equipment, and a central international office and staff is required for coordinating the work in general under an International Council. Provision for the latter is made in the Resolutions of the Conference 
(C, $\S 1-18)$, but the local arrangements are left to the respective Governments. In this matter the Conference merely draws the attention of each country concerned to the necessity of providing a specially constructed steamer for the scientific investigations (Resolution D). These steamers are to be employed in the regular investigation of predetermined areas adjoining the coasts of the respective countries. As will be seen from the programme $(A, \S 2)$, they are to make simultaneous quarterly cruises for the collection of the necessary physical observations, and are to be engaged in the intervals in the fishing and other experiments detailed in the biological programme.

It remains only to draw attention to the fact that the adhesion of the Continental Governments to the Scheme of International Explorations has already been signified, and that the work is announced to begin in May, 1902, at latest (cf. Resolution E).

The decision of the British Government has not yet been announced.

June 10th, 1901.

\section{MEETINGS OF THE CONFERENCE.}

ABSTRACT OF THE MINUTES.

(Translated and slightly abridged.)

$$
\text { Monday, May 6Th, } 1901 .
$$

12 noon.-Opening of the Conference in the reception hall of the University of Christiania by His Excellency the Prime Minister of Norway, Mr. Steen.

On behalf of His Majesty the King of Norway, Mr. Steen extended a cordial welcome to the members of the Conference. He said that they were assembled, as all knew, to draw up their final proposals for an international investigation of the North and adjacent seas. Repeated attempts on an isolated footing had been made to solve the problems of the sea and of the manifold life beneath its surface, and only after ripe experience had the different nationalities come to recognise that cooperation in their labours was essential to success. The task before them was not only an intellectual enterprise of the highest order, but also an application of knowledge in the service of the industrial life of society. It might be difficult to help the fisherman to know where to shoot his nets with the same certainty of a harvest as that with which the farmer manipulated his land and crops. Nevertheless, that was their aim; and if it were only approximately realised, sea-fishing would become the object of intelligent management, relieved of the caprices of chance which at present characterised it. Norway long ago took up and had constantly extended the scope of her scientific investigations 
upon the life and wanderings of food-fishes. The steamer which they had specially built and equipped for these inquiries had proved satisfactory in every way. As a consequence of their first investigations a new outlook had opened up for their fatherland, with its extensive seaboard and its rich fishing-banks: the prospect of obviating disappointments, the loss of time and labour, and the distress which followed in their train.

Repeating his wish that the labours of the Conference might lead to a satisfactory issue, Mr. Steen formally declared the opening of the proceedings of the Conference.

Dr. Herwig (Germany) thanked the Prime Minister for his good wishes, and spoke of the vast scientific and economic importance of the work which the Conference was to take in hand. As regards Germany, he was glad to say that she was contributing to the work not in name only but in deed, the National Assembly having voted both the money necessary for the construction of a special exploring vessel, and also a sum sufficient for the participation of the Empire in the scientific researches for a period of five years.

Prof. D'Arcy Thompson (Great Britain) and Dr. Knipowitsch (Russia) addressed His Excellency on behalf of the other countries represented, and associated themselves with Dr. Herwig's expression of thanks, recognising at the same time the active collaboration of the Norwegians in these scientific researches.

Upon the proposition of Dr. Herwig, Prof. Nansen was elected President of the Conference with acclamation.

Having taken the chair, Prof. Nansen thanked the Conference for the honour they had done him. He proposed to proceed without delay to the nomination of Vice-Presidents, one for each country represented, and for the sake of continuity proposed the re-election of those who had been Vice-Presidents at Stockholm; viz. Dr. Herwig (Germany), Capt. Drechsel (Denmark), Prof. Hoek (Holland), Prof. Pettersson (Sweden), and Dr. Knipowitsch, in the absence of Prof. von Grimm (Russia). As regards England, he proposed to await the arrival later in the day of Sir Colin Scott Moncrieff, Under-Secretary for Scotland. The Belgian delegates had not yet arrived.

These proposals were unanimously accepted.

The meeting adjourned at 1.15 p.m., to meet again at 2.30 p.m. in the reception room of the Grand Hotel, where the business of the Conference would be transacted.

2.30 p.m. $\quad$ Prof. Nansen (Norway) in the chair.

Present: All the delegates except those of Belgium and Prof. von Grimm, who was prevented by illness from attending. The British 
delegates, Sir Colin Scott Moncrieff, Mr. Garstang, and Dr. Mill, arrived at 3 o'clock.

It was resolved, on Dr. Herwig's proposition, to follow the same order of business as at Stockholm. The President proposed that they should take the Stockholm programme as the basis of discussion, and thought that a division into two sections, for hydrography and biology, would be unnecessary on this occasion. The Conference agreed.

Dr. Herwig (Germany) proposed that they should discuss the biological questions first, as these had been less elaborated than those relating to hydrography, and would consequently demand more time.

Prof. D'Arcy Thompson (Great Britain) approved of this suggestion, and the Conference accepted it.

Upon the proposition of Prof. Pettersson (Sweden), Dr. Hjort (Norway) was elected General Secretary.

Dr. Herwig, on behalf of the German delegates, submitted a draft programme of biological researches for the consideration of the Conference.

The Conference rose at 3.30 p.m.

\section{Tuesday, May 7Th.}

11 a.m. Dr. Herwig (Germany) in the chair.

Present: All the delegates except those of Belgium.

The Conference discussed the programme of biological investigations.

The Chairman submitted for consideration certain proposals of Drs. Hjort (Norway) and Petersen (Denmark), together with some suggestions of Dr. Knipowitsch (Russia).

After a preliminary discussion of various points before the general meeting it was resolved to entrust to a committee the task of drawing up a new biological programme, in which a distinction should be drawn between investigations obligatory upon all the states concerned (i.e. a minimum programme), and such investigations as were desirable, but not compulsory, for the participating states. In general, the proposals of Drs. Hjort and Petersen were to be taken as establishing the minimum programme. The questions of plankton and the bottom fauna were reserved for subsequent consideration.

Prof. Pettersson and Dr. Trybom (Sweden) drew attention to the fact that all the countries concerned would probably not be equally prepared for the collection of statistical data over their entire extent; and that for such countries the measurement of the fishes caught during the scientific expeditions should suffice.

Mr. Garstang (Great Britain) drew attention to a paragraph in the German proposals which dealt with investigations concerning the cap- 
ture of undersized fish. These had a special interest for England, and the British Government attached much importance to them.

Some further discussion took place concerning the German proposals as to the subdivision of territory for biological exploration among the different states.

Mr. Garstang proposed that the English Channel be included within the area of investigation, as being a channel of great importance for the supply of Atlantic water into the North Sea.

Prof. Nansen (Norway) recalled that it was decided at the Stockholm Conference to allot this territory to France and Belgium, if these countries should desire to take part in the international researches. Now that it was settled that France was not to participate, it was naturally to be desired that England and Belgium together would undertake to carry out the investigations in the Channel.

The general question of the delimitation of areas was then referred to committee for more ample consideration.

The following were elected members of the Biological Committee :Messrs. D'Arcy Thompson, Garstang, Heincke, Henking, Hjort, Hoek, Knipowitsch, Nordqvist, Pettersson, Trybom, with Dr. Gran as Secretary.

The Conference rose at 1.30 p.m.

Wednesday, May $8 \mathrm{TH}$.

11 a.m. Prof. Pettersson (Sweden) in the chair.

Prof. Krümmel (Germany) proposed that the hydrographical programme should be provisionally discussed in full congress. The resolution was accepted, and the successive paragraphs of the Stockholm programme passed under review.

A discussion arose as to the margin of time which might be allowed for the seasonal hydrographic cruises in order to satisfy the conditions as to simultaneity.

Messrs. Hjort (Norway), Knipowitsch (Russia), Drechsel (Denmark), and several others remarked that the operations, especially in northern waters and during the winter, would be attended by great difficulties, which might prevent the carrying out of the researches between narrow limits of time.

On the other hand, Mr. Ekman (Sweden) and others were of opinion that the hydrographic conditions changed so quickly in the more restricted areas (e.g. Kattegat, Skagerrak, North Sea) that the utmost simultaneity in the observations was desirable.

Upon the proposition of Messrs. Krümmel and Herwig the question was decided in the form given below (A. II., §2).

Various minor changes were made in the hydrographical programme, 
and Messrs. Krümmel and Mill were requested to incorporate the amendments in a revised programme to be submitted to the Conference for approval.

The meeting adjourned at 1.30 p.m.

\subsection{0 p.m.}

After the Chairman had communicated some telegraphic correspondence with the Belgian delegates, the Conference took up the consideration of the subjects of plankton and the bottom fauna.

A committee consisting of Messrs. Brandt, Cleve, Garstang, Heincke, Hoek, Knipowitsch, and Gran was appointed to draw up a set of proposals on these subjects in connection with the biological programme.

A committee consisting of Messrs. Krïmmel, Mill, and Pettersson was appointed to draw up resolutions-(1) as to the desirability of working up the hydrographic material according to the methods of Bjerknes and Sandström (see Resolution J); and (2) as to the desirability of arranging for co-operation with the proposed researches on the temperature of lakes announced by Prof. Forel, of Zurich (see Resolution K). Dr. Herwig assumed that these matters would involve no extra charge on the international budget. As regards the first, the Chairman announced that Sweden was prepared to pay the cost of preliminary researches on the matter; and he supposed that, if these inquiries yielded very important results, the other States, as well as Sweden, would desire to continue the work.

Thursday, May 9Th.

11 a.m. Prof. Hoek (Holland) in the chair.

The Chairman submitted the printed proposals prepared by the various committees; viz. :-

(1) Additions to the hydrographical programme;

(2) The programme of biological investigations; and

(3) The supplement to the latter in regard to plankton and the fauna and flora of the sea-bed.

The hydrographical programme was accepted without change.

The biological programme was then adopted, paragraph by paragraph, with slight modifications and additions proposed by Messrs. Heincke, Brandt, and D'Arcy Thompson.

Prof. Henking (Germany) proposed that statistical data should be accumulated, with the assistance of fishermen, according to the method followed at Geestemünde.

A committee consisting of Messrs. Garstang, Heincke, Hjort, Hoek, Krümmel, Mill, and Gran was authorised to fix the final form of the 
programme in accordance with the resolutions adopted by the Conference.

The Chairman read a telegram from the Belgian Government authorising the Belgian Consul to attend the Conference, owing to the illness of the delegates appointed.

The Conference rose at 1 p.m.

Friday, May 10Th.

10.30 a.m. Sir Colin Scott Moncrieff (Great Britain) in the chair.

The Belgian Consul, M. Andvord, was present.

The Chairman proposed the despatch of a telegram to the King of Norway.

The Council of Vice-Presidents was authorised to prepare and sign the telegram; to consider the question of the establishment of a Central Bureau; and to consider a proposition of the Chairman's relative to an international understanding with regard to the conditional prohibition of the use of fishing appliances, as for example in the Moray Firth.

Dr. Knipowitsch (Russia) proposed the addition of Mr. Nordqvist to the Council of Vice-Presidents, on the ground that Finland, although to be regarded as part of the Russian Empire, was participating in the explorations in a special manner, and was contributing the necessary funds on its own account. The proposition was accepted.

The Chairman proposed that Dr. Knipowitsch take the chair on the morrow; but the latter declined so that the final meeting might be presided over by Prof. Nansen.

The meeting adjourned at 11 a.m., and met again at 3.30 p.m.

The Chairman read the following telegram addressed to His Majesty :

$$
\text { À sa Majesté le Roi Oscar II., Stoclcholm. }
$$

Réunis à Kristiania pour continuer les travaux préliminaires dont le but est l'étude des Mers du Nord de l'Europe et qui ont été inaugurés si heureusement à Stockholm il y a deux ans,

nous nous souvenons avec une profonde et respectueuse gratitude de l'initiative de votre Majesté et du grand intérét qu' Elle a daigné témoigner à nos travaux.

L'exemple si élevé donné par votre Majesté, l'amour pour la science, montré à si differentes reprises, nous a encouragé et nous a été d'un très grand appui.

C'est grace à lui que nous comptons arriver avec nos délibérations à des résultats très favorables au developpement du bien-être humain.

(Signed by the President, Vice-Presidents, and General Secretary.) 
The Chairman announced that the Council of Vice-Presidents, at a private conference, had been occupied with various propositions concerning the central organisation. They had come to a unanimous agreement in regard to these propositions, which would be forthwith communicated to the Governments concerned, but could not be regarded as matters for discussion.

The Chairman submitted to the Conference a resolution, drawn up by the Council of Vice-Presidents, which was accepted (Resolution G, concerning the Moray Firth).

Mr. Garstang (Great Britain) submitted a resolution concerning the publication of an annual report, which was unanimously accepted (see C, $§ 4$ ).

Prof. Krümmel (Germany) submitted three resolutions, which were accepted (Resolutions D, H, J).

Dr. Mill (Great Britain) submitted a resolution, which was also adopted (Resolution $\mathrm{K}$ ).

The Conference rose at 5 o'clock.

Saturday, May 11Th.

11.30 a.m. Prof. Nansen (Norway) in the chair.

The following reply from His Majesty the King of Norway was read :-

\section{Congrès hydrographique, Kristiania.}

Très reconnaisant pour l'aimable télégramme des Présidents et Viceprésidents, au nom du Congrès, je fais des voux bien sincères pour le meilleur résultat de ses déliberations dans un but si utile et si intéressant."

Oscar.

M. Gilson, the Belgian delegate, read a programme of the researches which Belgium proposed to undertake as its share in the international explorations. He also proposed that M. Thoulet, Professor at the University of Nancy, should be invited to participate as if a member of the International Conference.

The Conference found it ultra vires to accept a proposition of this nature, while regretting that M. Thoulet was not included among the delegates.

The resolutions of the Stockholm Conference with regard to the central organisation were then approved after introduction of certain alterations (see below, Resolution C).

Dr. Herwig (Germany) submitted resolutions concerning the date at which the international explorations should commence, and concerning the first meeting of the International Council, which were accepted (Resolutions $\mathrm{E}$ and $\mathrm{F}$ ). 
The work of editing the minutes and arranging the Resolutions for publication was entrusted to a committee consisting of Messrs. Garstang, Heincke, Hjort, Knipowitsch, and Knudsen.

\title{
RESOLUTIONS OF THE CONFERENCE, UNANIMOUSLY ADOPTED BY THE UNDERMENTIONED DELEGATES.
}

\author{
Messrs. Brandt, Cleve, Drechsel, Ekman, Garstang, Heincke, Henking, \\ Herwig, HJort, Hoek, Knipowitsch, Knudsen, Krümmel, Mäckel, \\ Mild, Moncrieff, Nansen, Nordqvist, Petersen, Pettersson, D'Arcy \\ Thompson, Trybom, Wijkander.
}

Considering that a rational exploitation of the sea should rest as far as possible on scientific inquiry, and considering that international cooperation is the best way of arriving at satisfactory results in this direction, especially if in the execution of the investigations it be kept constantly in view that their primary object is to promote and improve the fisheries through international agreements, this International Conference resolves to recommend to the states concerned the following scheme of investigations which should be carried out for a period of at least five years.

Programme for the Hydrographical and Biological work in the Northern parts of the Atlantic Ocean, the North Sea, the Baltic and adjoining Seas.

A.

\section{THE HYDROGRAPHICAL WORK.}

I.

$\S 1$. The hydrographical researches shall have for their object: the distinction of the different water-strata, according to their geographical distribution, depth, temperature, salinity, gas-contents, plankton, and currents, in order to find the fundamental principles not only for the determination of the external life-conditions of useful marine animals, but also for weather forecasts for extended periods in the interest of agriculture.

II.

$\S 2$. As the hydrographical conditions are subject to seasonal changes, and as these strongly influence the distribution and life-conditions of useful marine animals, as well as the state of the weather and other general meteorological conditions, it is desirable that the observations should be made so far as possible simultaneously at definite points along 
the same determined lines in the four typical seasons, so that the middle of the period of working shall be in the first half of February, May, August, and November respectively. The Central Council shall decide how much variation in the date of the seasonal cruises is permissible, having regard to the natural conditions of the different regions in which researches are to be carried out.

\section{III.}

The observations referred to in II. would consist of :-

$\S 3$. Observations of temperature, humidity, and pressure of the air every two hours. Assmann's aspiration thermometer should be used, and self-registering instruments (thermometer and barometer) for interpolation.

Opportunities on board the ships should be afforded to the meteorological offices to make physical observations on the higher levels of the atmosphere by means of kites.

The other meteorological observations are to be carried out according to the methods adopted by the meteorological offices of the nations represented.

The observations, meteorological as well as hydrographical, made on board the special steamers at the time of the survey in the typical months, are to be immediately worked out under the supervision of the Central Bureau (see C) for publication in a Bulletin, wherein the conditions of the sea and the atmosphere are to be represented by tables and synoptic charts in co-operation with the meteorological institutes of the nations represented.

$\S 4$. The temperature of the surface water shall be taken every two hours or, when necessary, more frequently. It is desirable that selfregistering apparatus should be used for interpolation.

Observations on the vertical distribution of temperature are to be taken at the points mentioned in II., and should be taken regularly at intervals of $0,5,10,15,20,30,40,50,75,100,150,200,250,300,400$ metres, and so on; but all critical parts of the curve must be determined by extra readings.

The bottom temperature is to be investigated with all possible care.

$\S 5$. At every point and from every depth where the temperature is observed, a sample of water shall be collected for the determination of its salinity and density.

By salinity is to be understood the total weight in grammes of the solid matter dissolved in 1,000 grammes of water.

By density is to be understood the weight in grammes of 1 cubic centimetre of water of the temperature in situ $t^{\circ}$, i.e. the specific gravity in situ referred to pure water of $+4^{\circ}$ C. $\left(=S \frac{t^{\circ}}{4^{\circ}}\right)$. 
$\S 6$. Preliminary determinations of the salinity may be made on board ship with appropriate instruments, but the exact determinations of the salinity and density of water samples shall take place in a scientific laboratory on shore. The ratios between Salinity, Density, and Chlorine, given in Dr. Martin Knudsen's Hydrographic Tables, are to be adopted, and the salinity is to be calculated by the use of these Tables from the determinations of chlorine, or from the specific gravity.

$\$ 7$. At certain depths at the points mentioned in II. and elsewhere on the surface, water samples should be collected for analysis of the gas-contents (oxygen, nitrogen, and carbonic acid).

\section{IV.}

$\$ 8$. For measurement of depth the unit to be adopted is the metre, together with which the depth may be also recorded in English fathoms.

Geographical points are to be referred to the meridian of Greenwich, and horizontal distances are to be expressed in sea miles ( $=1,852$ metres).

$\$ 9$. Thermometers to be used for the determination of the surface temperature may be either centigrade or Fahrenheit, but for publication all numbers are to be reduced to centigrade.

In the centigrade thermometers for observation of surface temperatures, the distance between two degree marks should be at least $5 \mathrm{~mm}$., and the degree be divided into at least two parts, the Fahrenheit thermometer to be divided in a corresponding manner.

The use of an insulated water-bottle on Pettersson's principle is recommended for moderate depths, and the thermometers used for this apparatus should have a space of at least $10 \mathrm{~mm}$. between the marks of one degree, and the degree should be divided into 10 parts.

For greater depths of the ocean, reversing or other similar thermometers should be used.

The glass to be used for the thermometers should be tested and approved, and the thermometers periodically verified by the Central Bureau (see C. III. $\$ 12$ ).

$\$ 10$. For the determination of salinity and density, either chemical or physical methods may be adopted, provided that the salinity can be determined with an accuracy of 0,05 in a thousand parts (and the density up to 0,00004$)$.

The determination of these constants can be founded either upon chemical analysis of the halogen by weighing or titration, or upon physical determination of the specific gravity by means of the hydrostatic balance, pycnometer, and hydrometer, provided that measures be taken to exclude disturbances arising from thermal effects, capillarity, viscosity, etc. 
The same standard sea-water* shall be employed in all cases for standardising the solutions used for chlorine determinations.

The chemical analysis shall be controlled by physical methods, and the physical determinations by chemical analysis in the following manner: From every collection of samples examined at least three shall be selected and sent to the Central Bureau. Standard samples shall be sent in return.

\section{V.}

$\S 11$. Samples for gas analysis are to be collected in duplicate in sterilised vacuum tubes.

It is desirable that the existing tables of absorption of nitrogen and oxygen shall be revised.

VI.

$\S 12$. Qualitative plankton samples should be taken as frequently as possible from the surface by approximate methods simultaneously with the water samples, and also from deeper layers at the stations referred to in $\S 2$ (see below, B. VI., $§ 12$ ).

$\S 13$. Observations of the transparency and colour of the water should, when possible, be made at the same points.

\section{VII.}

$\S 14$. Observations on currents and tides should be carried out as frequently as the circumstances allow.

The currents should be examined, when possible, by direct currentmeters, and by surface and intermediate floats, and by bottom-rollers.

The ship should be anchored occasionally in order to make frequent observations during a complete period of tide.

\section{VIII.}

$\S 15$. It is desirable that a chart should be prepared, showing the nature of the deposits on the sea-bottom.

The description of the deposits is to be carried out on a definite plan, to be afterwards settled by the Central Bureau.

\section{IX.}

$\S 16$. The normal observations are to be carried out along the lines provisionally drawn on the annexed chart, where $R$ denotes the Russian, $F$ the Finnish, $S$ the Swedish, $G$ the German, $D a$ the Danish, $D u$ the Dutch, $N$ the Norwegian, and $B$ the British lines; but the Central

* By standard water shall be understood samples of filtered sea-water, the physical and chemical properties of which have been determined with all possible accuracy by analysis, and statements of which are sent to the different laboratories, together with samples. 


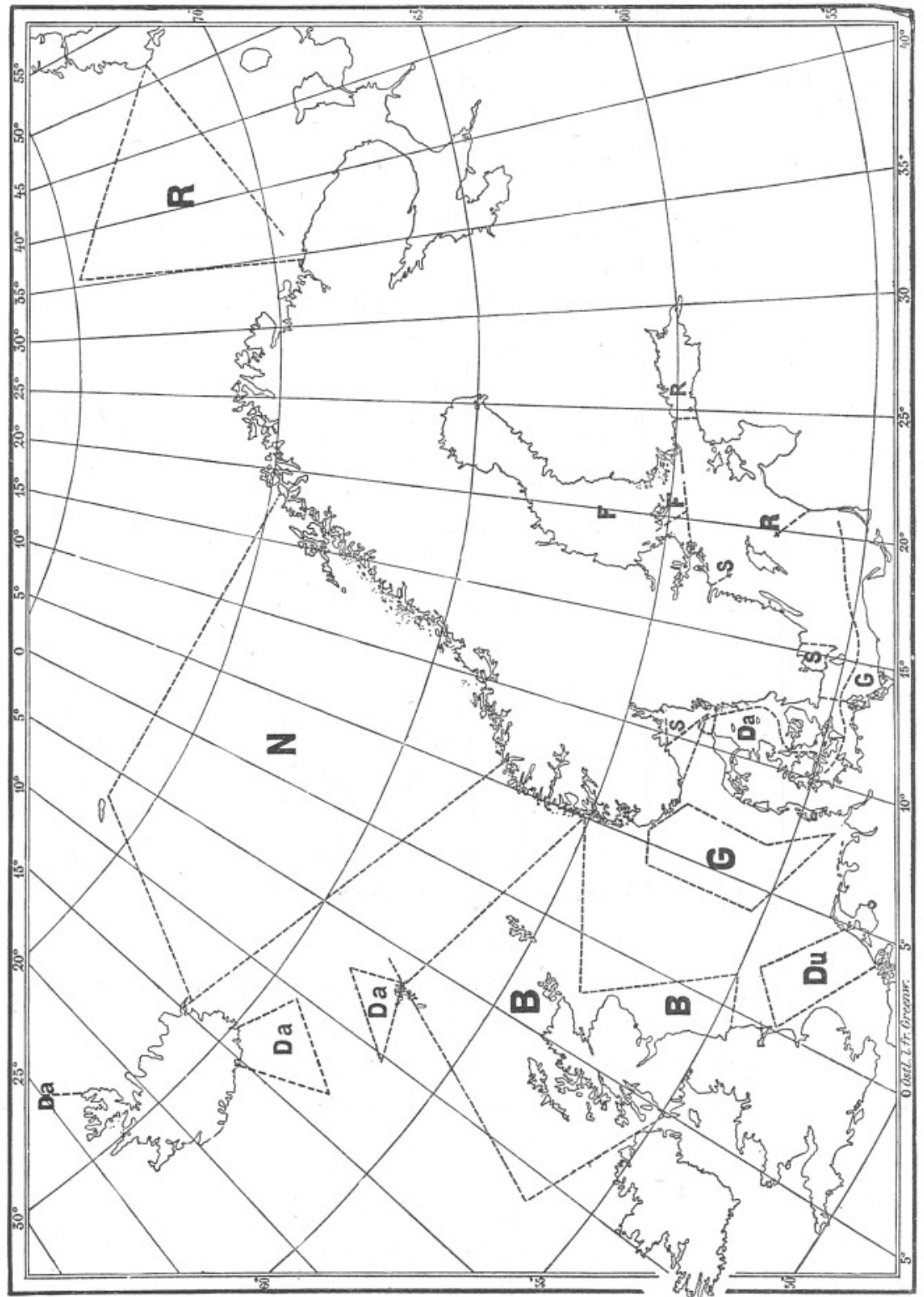

CHART SHOWING THE LINES OF OBSERVATION RECOMMENDED BY THE STOCKHOLM CONFERENCE, ADOPTED WITH SLIGHT MODIFICATIONS BY THE CHRISTIANIA CONFERENCE. 
Council shall have authority to make any necessary alterations in these lines, or in the regions where each nation is to work.

The special points are to be decided by the respective nations, and when once chosen the subsequent observations are to be repeated at the same points.

The special instructions for the work will also be given by the respective nations, and the communications as to the extent and the nature of the observations shall take place through the Central Bureau (see C).

X.

$\S 17$. It is desirable to supplement these investigations by making use of regular liners, light-ships, etc., and coast-stations for the purpose of taking temperature observations and collecting samples of sea-water and plankton. These observations are to be taken not only in the typical months, but also during the intervening periods.

B.

\section{THE BIOLOGICAL WORK.}

In each section of the programme which follows, note that-

Roman type indicates those investigations which all the participating countries undertake to carry out simultaneously.

Italics indicate those parts of the complete programme, the carrying out of which is desirable, but optional.

\section{Delimitation of Areas.}

I.

$\S$ I. It is recommended that each of the nations taking part in the international investigation should undertake the biological study of a definite area to be decided on as in the case of the hydrographical work and to correspond with the divisions adopted for that purpose.

The following is suggested as a preliminary division :-

A. North Sea south of $54^{\circ} \mathrm{N}$.

1. From $2^{\circ}$ E. eastward to Borkum Reef: Holland and Belgium.

2. From Borkum Reef to the Elbe: Germany.

3. From $2^{\circ} \mathrm{E}$. westward to the British coast, including the English Channel: Great Britain and Belgium.

B. North Sea, From $54^{\circ} \mathrm{N}$. TO $58^{\circ} \mathrm{N}$.

1. From $2^{\circ}$ E. eastward to Jutland and the Naze: Germany and Denmark.

2. From $2^{\circ}$ E. westward: Great Britain.

C. North Sea, north of $58^{\circ} \mathrm{N}$., and North Atlantic to about $62^{\circ}$

N. (the Faröes): Great Britain, Norway, and Denmark. 
D. Atlantic Ocean and Arctic Sea north of $62^{\circ}$ N.: Norway and Russia.

E. Skagerrak and Kattegat: Norway, Sweden, and Denmark.

F. Western Baltic: Germany, Sweden, and Denmark.

G. Eastern Baltic.

1. Southern part, extending to Bornholm and the Gothland bank on the north and to Memel on the east: Germany.

2. Northern part, including the Gulfs of Finland and Bothnia: Sweden, Russia, and Finland.

It is impossible, as well as undesirable, to draw a hard and fast line between the areas allocated to the various states, and of course the suggested boundaries are not intended to hinder any nation from extending its researches beyond the special areas agreed upon.

\section{BIology of Food-Fishes.}

II.

$\S 2$. Preparation of charts showing the distribution of plaice, sole, turbot, cod, haddock, and herring in the North and Arctic Seas, and of flounder, cod, sprat, and herring in the Baltic, in their different stages of growth, from the earliest stage which is passed upon the bottom up to the full-grown condition.

The investigations to this end are to be carried out as often as possible and, as far as possible, with uniform apparatus, e.g. with trawls of different size and mesh, drift-nets, hooks, etc. Measurements of all the fishes caught on each occasion are to be made in such a way as to yield a graphic representation of the relative number of the fishes at every stage of growth. The fullest possible data are to be given concerning sex, degree of maturity, and contents of stomach.

Each fishing operation is to be treated as a scientific experiment, and all the conditions of the experiment are to be carefully recorded (viz. place, depth, nature of bottom, state of water, wind and weather, rate and duration of haul, kind and size of net, etc.). The scheme submitted by Dr. C. G. Joh. Petersen to the Conference may be cited as an example of the journal record of a catch treated in this way.

$\$ 3$. Efforts should be made to secure a methodic investigation of all marine food-fishes as well as of the most important of those species which make regular migrations from fresh water to the sea, from the egg up to the full-grown condition, and with reference to development, growth, nutrition, reproduction, fecundity, distribution, migrations, and local varieties, and with constant reference to the hydrographic conditions of life. 
As the most important means of carrying out these investigations, fishing experiments of different kinds are to be undertaken in order 'to elucidate the distribution of food-fishes in the various parts of the sea. In this connection attention should be especially directed to the determination of the depths (whether on the bottom or in the intermediate layers of water) at which particular species of food-fishes can be caught.

It is much to be desired that labelled (or marked) fishes of important species (e.g. plaice, salmon, etc.) should be liberated in as large numbers as possible and over wide areas.

Special researches should also be directed to determine the extent to which important food-fishes are destroyed by their natural enemies.

$\S 4$. In connection with the fishing experiments it is desirable that investigations should be made to determine the extent to which the vitality of the fishes caught with the trawl and other fishing implements is affected thereby, and whther such fishes are, or are not, in a condition to live after liberation.

\section{III.}

$\S 5$. Determination of the quantitative distribution of the eggs, pelagic larvæ, and young fishes of the species mentioned in II. $§ 2$, during the periodic cruises proposed in the hydrographic programme and at the stations fixed for those cruises.

The investigations are to be carried out, firstly, by vertical hauls with Hensen's large egg-net, and secondly, with larger horizontal nets adapted thereto.

$\S 6$. It is further desired that the eggs and larve of the above-mentioned food-fishes should also be collected and accurately studied in the intervals between the hydrographic cruises, and especially during the spawning periods of these fishes.

$\S 7$. Experiments are further desired upon the artificial fertilisation and hatching of the eggs of the most important of the food-fishes mentioned, not only on the steamers for scientific work, but also on board commercial fishing-vessels and on shore.

IV.

$\S 8$. Investigations upon the local varieties of plaice, herring, and mackerel in the entire international area of research are to be assisted by the collection of suitable material in all countries, to be placed at the disposal of individual specialists for detailed investigation, through the agency of the Central Bureau.

$\$ 9$. It is desirable that such investigations should be extended also to other useful species of animals. 
V.

$\S 10$. With reference to the question of the extent of the destruction of immature (undersized) fish in the ordinary practice of sea fishing, it shall be a primary object of the fishing experiments to delimit those parts of the sea in which young food-fishes, especially plaice and haddock, occur in great abundance, and to subject these regions to exact biological investigation.

Attempts shall also be made in the larger fishing ports of the North Sea to determine the relative number of such young food-fishes below the average size of maturity (especially plaice and haddock). which are landed by the different methods of fishing, and at different times of the year.

$\$ 11$. It is desirable to determine the amount of the catches of immature (undersized) food-fishes, especially of plaice and haddock. To this end the official statistical records in the fishing ports should be utilised in the first place, and in the second place the fishing experiments and the analysis of their catches as specified under II. $\$ 2$, and $V$. 10 . Still richer material will be obtained, if favourable opportunities also occur for sending competent experts on board fishing vessels, in order to determine exactly the quantity and size of the immature (undersized) fishes on the fishing grounds themselves, and to record the same for each catch according to a uniform scheme to be determined.

\section{Plankton and Bottom Fauna.}

VI.

$\S 12$. Qualitative plankton samples are to be taken as often as possible during the hydrographic seasonal cruises, and not merely from the surface, but also by vertical hauls.

$\S 13$. It is desirable that qualitative planteton samples should also be regularly taken in large quantity on other cruises and at definite coast stations, in order to provide plentiful material for more detailed study of the plankton from systematic biological and chemical points of view. The use of closing nets and water-bottles, as well as the filtration of the smallest organisms, is recommended.

\section{VII.}

$\S 14$. If circumstances permit, quantitative hauls shall be taken with Hensen's plankton-net at the chief hydrographic stations, and be placed through the agency of the Central Bureau at the disposal of those investigators who are prepared to undertake a thorough quantitative investigation. 
$\$ 15$. Control experiments to check the accuracy of the quantitative methods are desirable, as well as quantitative hauls for chemical analysis.

\section{VIII.}

$\S 16$. Endeavours shall be made with suitable apparatus to investigate more exactly the organisms which inhabit the lowest water layers immediately above the bottom.

$\$ 17$. Quantitative investigations of this material are also to be desired.

\section{IX.}

$\S 18$. Systematic investigations upon the macroscopic animal and plant life of the bottom, with special reference to the nutrition of foodfishes.

$\$ 19$. More detailed investigations are desirable upon the bottom fauna and flora in general, as well as with reference to their dependence on the physical and chemical conditions of the ground.

Efforts should be made to determine the general topography of the bottom fauna, in order to bring the main faunistic regions into relation with our knowledge of hydrographical conditions, and the distribution of mavine food-fishes.

Opportunities should also be given to bacteriologists to carry out investigations upon the bacteria of the sea-bottom, as well as of the overlying water, and to make determinations of the inorganic nitrogenous compounds present in the water.

\section{Fishery Statistics.}

$\mathrm{X}$.

$\S 20$. Elaboration of uniform critical statistics of the sea-fisheries of the participating states, especially giving particulars of the food-fishes landed from those parts of the sea which lie within the international area (especially from the Norwegian and North Sea), according to species, place of capture, time of capture, number and weight.

Particular care is to be given to the preparation of exact statistics of the herring fishery, according to place, time of year, degree of maturity, and dependence on special hydrographic conditions.

Material shall be collected for the preparation of fishery charts, on which the different fishing grounds, and the fisheries conducted thereon, shall be inserted.

$\$ 21$. In connection with the fishery statistics it is also desirable to determine as precisely as possible the fishing grounds from which the individual catches have been derived. Above all, in the ground-net fisheries 
should the attempt be made, with the assistance of reliable owners and captains of a large number of fishing vessels belonging to important ports, to obtain exact details concerning their catches, as regards place of capture, duration-of fishing, species and amount (both number and weight), and to record these details in uniform schedules to be agreed upon.

C.

ORGANISATION OF AN INTERNATIONAL COUNCIL, A CENTRAL BUREAU, AND AN INTERNATIONAL LABORATORY.

The Conference recommends for the international hydrographic and biological investigation of the seas the establishment of an International Council with a permanent Central Bureau and an International Laboratory.

I.

$\S 1$. The permanent International Council shall consist of commissioners elected by the Governments interested. Each Government should appoint two commissioners who may be represented at meetings by substitutes, and may be accompanied by experts who, however, shall not be competent to vote.

$\S 2$. The Council elects its President and Vice-President, and appoints all officials of the Central Bureau. Should the General Secretary represent hydrographical science, one of his principal assistants should be a biologist, and vice versa. The other assistant shall preferably be experienced in statistical work.

$\S 3$. The Council shall draw up its own order of proceedings.

$\S 4$. The Conference recommends that the Central Council shall issue, in addition to the ordinary periodical Bulletins, an Annual Report which shall include-

(1) A summary of the work done in each year by the participating countries in carrying out the international programme; (2) an announcement of those discoveries which are of direct practical importance for the fishing industry ; and (3) a statement of such recommendations for international action as in the unanimous opinion of the Central Council follow clearly from the international investigations.

$\S 5$. It will be for the Governments concerned to decide among themselves the amount of the contributions to the central organisation.

The expenses of the central organisation are approximately estimated at $£ 4,800$ (96,000 mark) yearly. 
Estimate of the Expenditure of the Central Organisation.

1. General Secretary $\underset{750}{\stackrel{2}{ \pm}}$

2. Two principal Assistants . . . . . 750

3. President, for incidental expenses other than travelling expenses . . . . . . 200

4. Vice-President, for incidental expenses other than travelling expenses . . . . . . 100

5. Office, scientific and technical assistants, draughtsmen, clerks, servants, postage, telegrams, and similar expenses $\quad . \quad$. $\quad . \quad . \quad 1,350$

6. International laboratory . . . . 650 *

7. Travelling expenses . . . . . 300

Note: Travelling expenses of commissioners attending meetings of the Council shall be borne by their respective Governments.

8. Printing

9. Incidental expenses

II.

The purpose of the Central Bureau will be-

$\S 6$. To give uniform directions for the hydrographic and biological researches in accordance with the resolutions drawn up in the programme of the present Conference, or in accordance with such modifications as may be introduced later with the consent of the states represented.

$\S 7$. To undertake such particular work as may be entrusted to it by the participating Governments.

\$. To publish periodical bulletins which shall contain the actual data obtained in the cruises of all the participating states at the earliest possible date, and also such other papers as may prove useful in coordinating the international work.

$\S 9$. To make proposals for the graphic representations, scales, signs, and colours to be used in the charts for the purpose of obtaining uniformity in the publications, the decision regarding which shall rest with the International Council.

$\S 10$. In connection with the investigations, to make application to the telegraph administrations for the purpose of obtaining determinations from time to time of the changes in the resistance of the cables which cross the areas in any direction.

* To this sum is to be added a proposed extra grant from the Norwegian Covernment. 
$\S 11$. The site of the Central Bureau, to be decided by the Governments concerned, shall at the same time be the residence of the General Secretary.

III.

The purpose of the International Laboratory shall be-

$\S 12$. To control apparatus and to ensure uniformity of methods.

The various apparatus and instruments now used for oceanic research should be examined, in order to settle which are the most trustworthy. Experiments may also be made to improve the apparatus and instruments, or to construct new and better ones.

$\S 13$. The water-samples sent by the workers of the participating states are to be analysed and examined at the central laboratory, from which also samples of standard water should be provided.

$\S 14$. In the central laboratory various important investigations of general interest for oceanic researches may be carried out. The various methods for determining salinity, temperature, gases, plankton, etc., of the sea should be carefully tested, in order that standard methods may be fixed.

$\S 15$. Facilities should be afforded to the participating states for sending students to the central laboratory to be trained for oceanic researches.

$\S 16$. The investigators of the participating states, or special expeditions, may, if desired, be supplied from the central laboratory with instruments, apparatus, etc., for oceanic research at cost price.

$\S 17$. The International Laboratory is subordinate to the Central Council, to which its accounts shall be rendered. Its operations shall be reported to the Central Bureau.

$\S 18$. The site of the central laboratory shall be decided by the Governments concerned, and should be conveniently situated for oceanic researches.

D.

The Conference considers it absolutely indispensable that each of the countries concerned should provide a steamer specially constructed for scientific fishery researches.

E.

It is very desirable that the first periodical cruise should take place as soon as possible, but be not postponed beyond May, 1902, at latest.

The Central Bureau shall commence operations as soon as possible, but not later than the beginning of 1902 . 
F.

The Conference recommends that the International Council should meet at Copenhagen as soon as the participating Governments have definitely accepted the programme of the Conference; and if that should not be possible, that each Government should send a delegate (accompanied, if desired, by specialists) with full powers to decide what regulations should be made for the prompt constitution of the Central Bureau.

G.

In distinct areas of the sea, as for instance the Moray Firth, in which any Government has undertaken scientific experiments in the interest of the fisheries, and in which the success of the experiments is being hindered by the operations of trawlers, it is to be desired that measures be adopted for the removal of such hindrances.

H.

The Conference recognises the extreme value of Dr. Martin Knudsen's hydrographic tables, and expresses its cordial thanks to him for his admirable work.

The Conference desires that the Central Bureau should be authorised to pay the balance of the expenses of the investigation not covered by the grants already received from Governments and scientific institutions, either out of the general funds, or from any special grants made for the purpose.

J.

The Conference considers it desirable that the hydrographic material should not only be published by the Central Bureau in tabular form, but also that the results should be worked up in such a form as to elucidate the currents of the different layers of water and their relations to wind and to differences of density as motive agencies, by methods similar to those of Mohn and Bjerknes.

\section{K.}

The Conference considers it desirable that the International Association for Limnological Studies should, as far as possible, adopt for the investigation of lakes the methods and times of observation approved by this Conference for the study of the sea; and recommends that the Central Bureau should arrange for the regular exchange of the observations made on lakes and on the sea. 


\title{
L.
}

The Conference desires to repeat the declaration of the Stockholm Conference that it is of the greatest importance, both for deep-sea fisheries and for the weather forecasts for long periods, that the Faröe Islands and Iceland should be included in the European telegraph system as soon as possible.

\author{
(Signed) Nansen, President. \\ Hзort, General Secretary.
}

